\title{
Engineering Geological Investigation of dam site of proposed Sunkoshi-2 Hydropower Project, Khurkot area, eastern Nepal
}

\author{
*Bipin Adhikari ${ }^{1}$, Ujjwal Acharya ${ }^{2}$, Kamala Kant Acharya ${ }^{1}$, and Subesh Ghimire ${ }^{1}$ \\ ${ }^{1}$ Central Department of Geology, Tribhuvan University, Kirtipur, Kathmandu, Nepal \\ ${ }^{2}$ Center for Geo-environment and Engineering Research, Kupondole, Lalitpur, Nepal \\ *Corresponding author: bpnadhi09@gmail.com
}

\begin{abstract}
The dam site of proposed Sunkoshi-2 Hydropower Project and its surrounding mainly comprise the Tawa Khola Formation, which is the basal formation of the Bhimphedi Group. Although garnet schist and micaceous quartzite bands are the main rock types; three rock units namely- Schist Unit, Quartzite Unit, and Gneiss Unit were identified. Engineering geological mapping followed by discontinuity survey were carried out. The result exhibited differences in fracture intensity and discontinuity characteristics of rock masses according to rock type. Since joint orientations were found to be consistent over fairly large areas, surface studies of joints were used in predicting subsurface orientations. Rock mass classification was made in line with the Rock Mass Rating System (RMR) and the Dam Mass Rating (DMR) classification for the dam foundation. The rock masses were classified onto fair to good rock classes according to RMR value. Dam foundation analysis regarding stability against sliding using DMR classification helped in selection of suitable dam-axis among two alternatives. Water Quality Standards (2005).
\end{abstract}

Keywords: Tawa Khola Formation, Discontinuity Survey, Rock Mass Characterization, RMR, and DMR

Paper Received: 15 Jan 2019

Paper Accepted: 8 Apr 2019

\section{INTRODUCTION}

Hydroelectric power projects are pollution free and renewable source of energy. Most of these projects involve the construction of dams across a flowing river. Construction of dams requires stability analysis of the foundation at abutment, as well as the supporting rocks at the slopes of the reservoir area. Regarding the increasing demand of electricity in the country, the Government of Nepal, Department of Electricity Development has approved a program to conduct the feasibility study of two large hydropower projects in the Sapta Koshi Basin and has selected a number of sites that may be suitable for the construction of storage dams. Sunkoshi 2 Hydropower Project has been planned as a reservoir type hydropower project having dam height $166 \mathrm{~m}$ and capacity 1,110 MW. This study provides a basis for estimating deformation and strength properties of the rock mass for preliminary design calculation.

The study area lies in parts of Sindhuli and Ramechhap districts positioned within the latitude $27^{\circ} 14^{\prime} 00^{\prime \prime}$ to $27^{\circ} 29^{\prime} 30^{\prime \prime}$ and longitude $85^{\circ} 47^{\prime} 30^{\prime \prime}$ to $86^{\circ} 10^{\prime} 20^{\prime \prime}$. The area comprises the proposed site for Sunkoshi-2 Hydropower Project (Fig. 1). Its dam site is near the Kudule Village at a distance of about twenty kilometers along the Pushpalal Highway (under construction) from its beginning at Khurkot.

The type and design of individual dams depends on factors such as volume of water to be stored, topography, geology, and type and amount of local material available for constructing the dam. In order for any structure to be safely built in a rock mass, an adequate understanding of the rock mass properties is essential. Achieving this understanding requires a sufficient amount of rock mass data to be collected. Study utilizing rock mass classification systems including RMR (Bieniawski, 1989) and DMR (Romana, 2004) have been applied

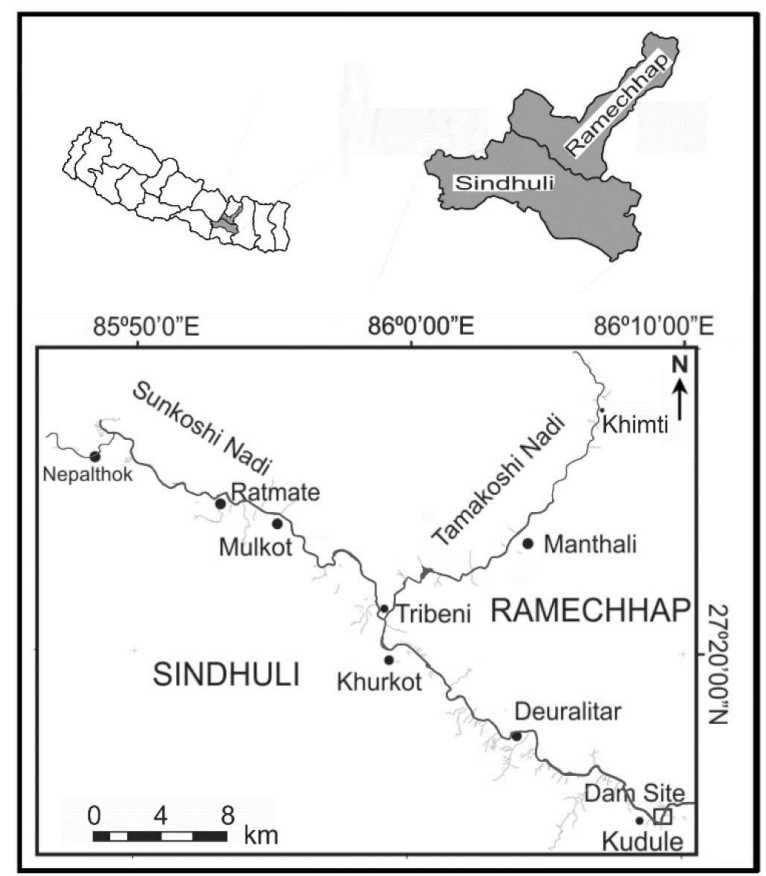

Fig. 1: Location map of the study area 
to characterize and compare the rock masses exposed in the dam abutments and foundation area at two suitable dam-axes of the proposed dam sites. Structural mapping fieldwork undertaken as an essential part of the research proves itself to be fruitful in understanding the spatial properties of discontinuities and their significance in the stability of the ground mass and permeability to the movement of fluids which essentially focuses on intactness and proper functioning of the dam.

\section{GEOLOGICAL SETTING}

Shrestha et al. (1984) compiled the geology of the eastern Nepal and published a compiled map from the Department of Mines and Geology (DMG). They divided the rocks of the area into the Midland Group and the Kathmandu Group. These two groups are separated by the MCT. They further divided the Midland Group into the Ulleri Formation, Kushma Formation, Seti Formation, Naudanda Formation, Ghan Pokhara Formation, Galyang Formation, Sangram Formation, Syangja Formation, Lakharpata Formation and the Takure Formation in ascending order. Similarly, they divided rocks of the Kathmandu Group into the Dware Kharka Schist, Panglema Quartzite, Himal Gneiss, Shiprin Khola Formation, Udaipur Formation, Maksana Formation, Tawa Khola Formation, Sarung Khola Formation in ascending order (Fig. 2). The dam site of proposed Sunkoshi2 Hydropower Project and its surrounding comprise mainly the Tawa Khola Formation, which is the basal formation of the Bhimphedi Group. Apart from garnet schist and micaceous quartzite bands as the main rock types, three rock units namelySchist Unit, Quartzite Unit, and Gneiss Unit were identified.

\section{ENGINEERING GEOLOGICAL INVESTIGATIONS}

The gneiss is regional and contain large kyanite crystals (up to $2 \mathrm{~cm}$ length and $3 \mathrm{~mm}$ diameter), garnet (about 3 to $5 \mathrm{~mm}$ diameter), granite and pegmatite intrusions as well as parasitic folds and asymmetric augens. However, it was observed that some area contains rock exposure with dominating gneiss, whereas some sections contain mainly schists and quartzites. Strength of rocks at outcrops varied greatly even when assessed in more or less fresh exposures at road-cuts and cliffs. Further classification of rock type and soil as 'engineering geological units' was made showing rock and soil assemblages of more or less uniform geotechnical properties (as estimated at the field). The rock exposures have been extrapolated at many places during mapping to provide information of complete outcrops, most of which include lesser than 1-meter (approximated) colluvial cover.

\section{Soil classification}

Different types of Quaternary deposits with unique mode of origin, spatial distribution, and geotechnical properties were observed and classified using field methods. Types of soil were classified and mapped as follows:

Manual accumulation: The soil often accumulated in cone shape at foot of hill adjacent to alluvium at river bank. It is composed mainly of crushed rock fragments and finer particles, disposed from the excavated slopes for constructing the road, scattering below the road (i.e. right bank of the Sunkoshi Nadi) Therefore, this type of soil was classified under 'talus deposit'. However, cone shaped deposits of gravity transported rockfragments at foot of some slopes were also included in the same category.

Alluvium: Found spreading on riverbed and floodplain, composed mainly of pebble gravel and boulder, with certain sorting property, partial floodplain is covered with sand layer. Near the dam-axis, the particle size is mostly $3-25 \mathrm{~cm}$, mainly of pebble gravels with large blocks; downstream of the dam site is mainly of erratic boulder in secondly angular shape.

Colluvium: This type of soil derived due to accumulation of mechanically and chemically disintegrated blocks and fragments and include particles of varying shape and size mixed with finer particles (about 50\%) and form thin (1 to $3 \mathrm{~m}$ ) to thick ( 3 to $10 \mathrm{~m}$ ) cover mainly near the lower part or at toe of slopes. In this class, slope wash deposits essentially comprising gravelly soil and few larger blocks with wide gap of particle size, mostly spreading at the slope toe of steep and straight hill segments were also included.

Diluvium: Comprised mainly of angular shaped large blocks, held by matrix of fine sand and silt, exhibiting heterogeneity in particle size. Composition and material properties were noted to be intermediate between alluvium and colluvium. The soil was related with flash flood deposits found spreading in gullies on both banks and at the distal part of gullies in fan shape.

Residual: Matrix of fine soil (greater than $50 \%$ ) with occasional, altered and randomly oriented litho-relicts were observed forming a belt along the flat part of ridges. The soil as formed in-situ due to weathering was cohesive in nature and lacked relict fabric, hence classified as 'residual soil'.

\section{Weathering of rock masses}

Since weathering state of rock mass has great influence in their engineering properties, assessment of weathering followed by its description and zonation was carried out.

Unlike uniform weathering in which a gradual decrease of weathering grade and intensity with depth (in thick strata of homogeneous lithology), the study area (particularly dam site area) exhibited complex weathering. Irregular weathering profile was noted due to varying lithology with different susceptibilities to weathering. Due to this reason, symbols denoting grade of weathering were not included in engineering geological map.

Most of the rock masses that were studied at exposures during rock mass classification and discontinuity surveying were slightly weathered due to the interaction with water. Brown 
staining by the oxidation of iron bearing minerals was observed at the foliation surfaces with considerably wide aperture. Mechanically disturbed rock mass (i.e. highly fractured) were found to be more suffered from such weathering. Only surface straining was observed in micaceous quartzite, white quartzite, and augen gneiss. Remaining rock masses composed of banded gneiss, and schists were found moderately to highly weathered.

\section{Distribution of rock units}

As shown in engineering geological map of the dam site area (Fig. 3) the rocks are dipping southwards. Micaceous quartzite which is gray colored medium grained impure quartzite, is the dominant lithology. In the northern part of the map, bedrocks of augen gneiss with dark gray to black pelitic schist

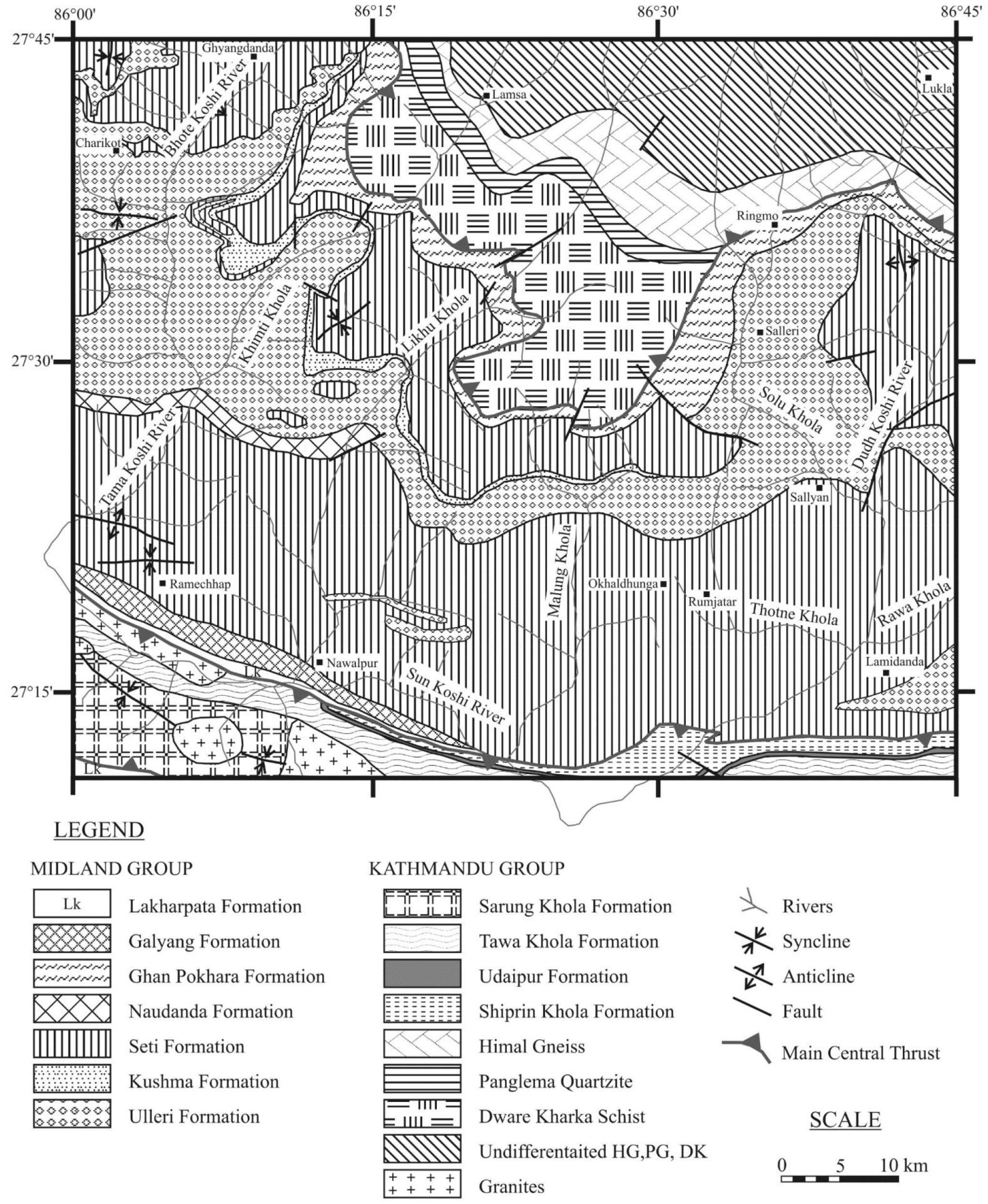

Fig. 2: Geological map of the eastern Nepal (Modified from Shrestha et al., 1984) 


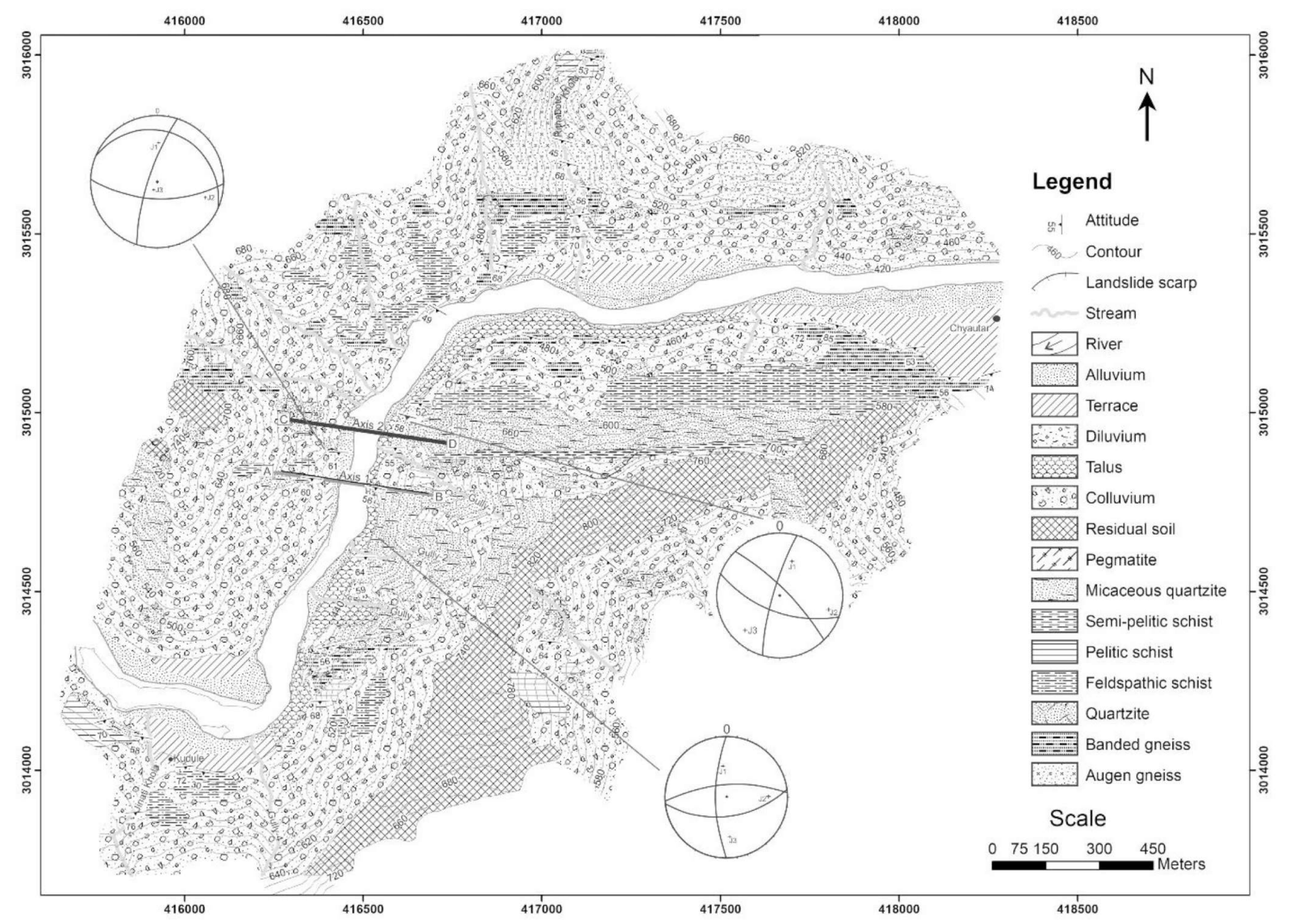

Fig. 3: Engineering geological map of the dam site area near the Kudule Village

and few banded-gneiss are shown, these were observed at many exposures along the Rithabote Khola section. Well-developed kyanite crystals and garnets (about 3 to $5 \mathrm{~mm}$ diameter) were noted in banded-gneiss; such mineralization was also noted in and at the periphery of asymmetrical feldspar augen in gneiss.

Stratigraphically upwards (i.e. southwards), downstream along the Rithabote Khola, about $150 \mathrm{~m}$ upstream from its confluence with the Sunkoshi Nadi, moderately weathered exposures of dark-gray feldspathic schist were observed. Garnet were also observed in these rocks. Along the right bank of the river alternating bands of gneiss and coarse-grained white quartzite were observed while moving towards the Chyakutar Village located $2.5 \mathrm{~km}$ downstream from the dam-axis. Several pegmatite intrusions ( $\sim 2 \mathrm{~m}$ length and 40 to $50 \mathrm{~cm}$ width) with kyanite and garnet in and around them were noted in gneiss. Gneissic appearance of schists due to numerous quartz veins and lenses developed in them was common. White quartzite as 10 to $12 \mathrm{~m}$ thick bands which composed laminae preserved as primary structure indicating their sedimentary origin were seen.

After nearly $200 \mathrm{~m}$ upwards, the lithology was found changed to gray fine- to medium-grained micaceous quartzite, in which 15 to $20 \mathrm{~m}$ continuous section was noted to be slightly calcareous. Similar band of calcareous rock was noted at the left bank of the river which was roughly located at the opposite bank. Afterwards, in the immediate upstream of dam-axis B, about $30 \mathrm{~m}$ thick strata of semi-pelitic schist was observed. The rock type appeared just after Gully-3, crenulation cleavage and small-scale folds ( 1 to $2 \mathrm{~m}$ in dimension) were exposed. One of those folds was observed and its trend/plunge was found $3150 / 280$. The schist was found overlain by micaceous quartzite with numerous pegmatite intrusions concordant with the plane of foliation. However, at the 'dam-axis A' the intrusions were rarely found and started to increase towards upstream. About $125 \mathrm{~m}$ southwards from Gully-3, thick bands ( 3 to $5 \mathrm{~m}$ ) of shiny-gray pelitic schist within micaceous quartzite and banded gneiss was observed. Feldspathic-schist with reddish-brown garnet, and veins and lenses of quartz were observed in the area near Kholse-4, forming about $300 \mathrm{~m}$ thick succession. Micaceousquartzite with abundant quartz veins was observed exposed along bed of the Jinati Khola and steep cliffs at its bank.

\section{Rock mass classification}

Rock Mass Rating System (After Bieniawski, 1989) was used for the determination of rock mass quality at foundation and abutments. RQD was calculated using the equation proposed by Palmström (2005) as RQD $=110-2.5 \mathrm{Jv}$ (for $\mathrm{Jv}$ between 4 
Table 1: Rock mass rating at abutments

\begin{tabular}{|c|c|c|c|c|c|c|c|c|}
\hline & Rock type & UCS & RQD & $\begin{array}{l}\text { Spacing } \\
\text { (Rating) }\end{array}$ & $\begin{array}{c}\text { Condition of } \\
\text { Discontinuity } \\
\text { (Rating) }\end{array}$ & $\begin{array}{l}\text { RMR } \\
\text { Value }\end{array}$ & $\begin{array}{l}\text { Rock } \\
\text { class }\end{array}$ & Classification \\
\hline $\begin{array}{c}\text { Axis } 1 \\
\text { Left abutment }\end{array}$ & $\begin{array}{l}\text { Micaceous } \\
\text { quartzite }\end{array}$ & Strong & Good & 8.6 & 23 & $65-70$ & II & Good rock \\
\hline Right abutment & $\begin{array}{l}\text { Micaceous } \\
\text { quartzite }\end{array}$ & Very strong & Good & 12.5 & 22.5 & $69-73$ & II & Good rock \\
\hline $\begin{array}{c}\text { Axis } 2 \\
\text { Left abutment }\end{array}$ & $\begin{array}{l}\text { Micaceous } \\
\text { quartzite }\end{array}$ & $\begin{array}{l}\text { Strong to very } \\
\text { Strong }\end{array}$ & $\begin{array}{c}\text { Fair to } \\
\text { good }\end{array}$ & 10.5 & 24.5 & $72-76$ & II & Good rock \\
\hline Right abutment & $\begin{array}{l}\text { Semi-pelitic } \\
\text { schist }\end{array}$ & $\begin{array}{l}\text { Medium strong } \\
\text { to strong }\end{array}$ & Fair & 8.2 & 21 & $54-57$ & III & Fair rock \\
\hline
\end{tabular}

Table 2: Calculation and results of DMR for foundation strata below dam-axis 1

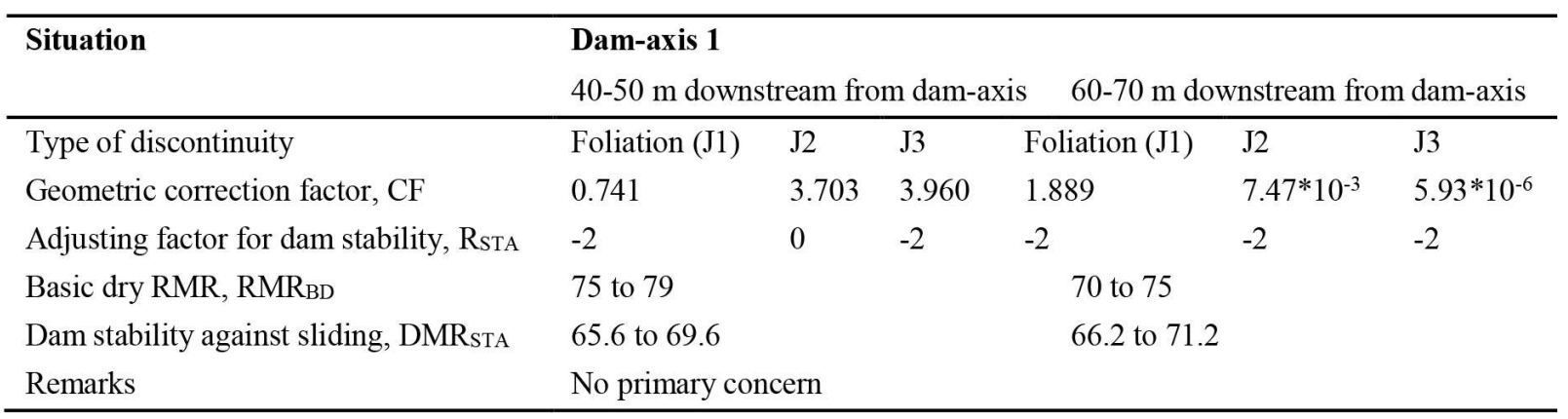

and 44). The Uniaxial Compressive Strength of the rock was judged from the simple hardness tests in the field with a geological hammer by observing the resistance to breaking under impact as given in the method by ISRM (1978). Results of rock mass rating are shown in Table 1. DMR (Dam Mass Rating), proposed by Romana (2004), giving tentative guidelines for several practical aspects in dam engineering and appraisal of dam foundations was applied as used by Shafiei and Maurice (2007) at the Proposed Khorram-Roud dam site in western Iran. Dam Mass Rating was performed regarding the orientation of significant discontinuities at both the abutments and results are listed in Table and Table 3.
As shown in the engineering geological map (Fig. 3), comparison of valley geometry, geomorphology, and rock mass properties of strata for foundation and abutment was carried out. Gullies exist in front of the dam-axis at the right bank and downstream of the dam on left bank, and the weak and deformed rock mass on the right bank. Width of valley bottom was measured about $80-100 \mathrm{~m}$, at the elevation of $420 \mathrm{~m}$ at damaxis 1 , while it was measured 110 to $125 \mathrm{~m}$ along 'dam-axis 2' as shown in Figs. 4 and 5.

The results of RMR at abutments indicate superiority of 'dam-axis 1 ' as the rocks at right abutment of 'dam-axis 2' are lower in rating (Tables 1 and 2).

Table 3: Calculation and results of DMR for foundation strata below dam-axis 2

\begin{tabular}{|c|c|c|c|c|c|c|}
\hline \multirow{3}{*}{$\begin{array}{l}\text { Situation } \\
\text { Type of discontinuity }\end{array}$} & \multicolumn{6}{|l|}{ Dam-axis 2} \\
\hline & \multicolumn{3}{|c|}{$40-50 \mathrm{~m}$ downstream from dam-axis } & \multicolumn{3}{|c|}{$60-70 \mathrm{~m}$ downstream from dam-axis } \\
\hline & Foliation (J1) & $\mathrm{J} 2$ & $\mathrm{~J} 3$ & Foliation (J1) & $\mathrm{J} 2$ & $\mathrm{~J} 3$ \\
\hline Geometric correction factor, $\mathrm{CF}$ & 0.500 & 3.939 & 1.242 & 1.377 & 3.978 & 0.181 \\
\hline Adjusting factor for dam stability, RSTA & -2 & -2 & -2 & -2 & -2 & -2 \\
\hline Basic dry RMR, RMR $\mathrm{BD}$ & 72 to 77 & & & 65 to 70 & & \\
\hline Dam stability against sliding, DMRsTA & 60.6 to 65.6 & & & 54 to 59 & & \\
\hline Remarks & Concern & & & & & \\
\hline
\end{tabular}




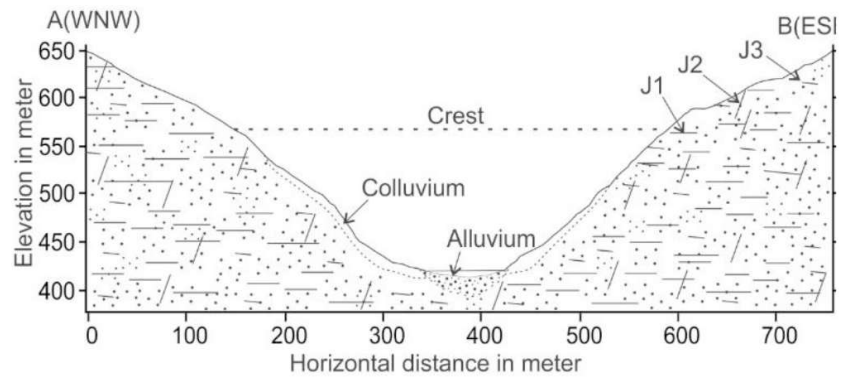

Fig. 4: Cross-section along dam-axis 1

\section{Discontinuity survey}

More than three hundred fracture data were recorded for analysis using scan-line survey. A high percentage of colluvial cover restricted discontinuity visibility, particularly on the left bank. Three dominant discontinuity sets along with the foliation were determined both on the left and right bank of the proposed dam. Other joints were random in orientation. The findings of discontinuity surveying at different locations are graphically presented (Fig. 6 and Fig. 7).

Discontinuity analysis gave quite random results regarding the surface characteristics and aperture formed in joints. Random measurement of attitude of discontinuity planes during the data acquirement for kinematic analysis in the dam site area, more than three data were gathered. The ranges of average (regional) orientation of rocks around the dam site area was found as shown in (Fig. 6) rosette diagram and major properties of discontinuities as shown in Fig. 7. The dominant joint set i.e. the foliation plane and quartz-feldspar lenses and veins were more or less parallel indicating concordant bodies, trending joint and vein sets were mutually cross cutting, and mutually abutting.

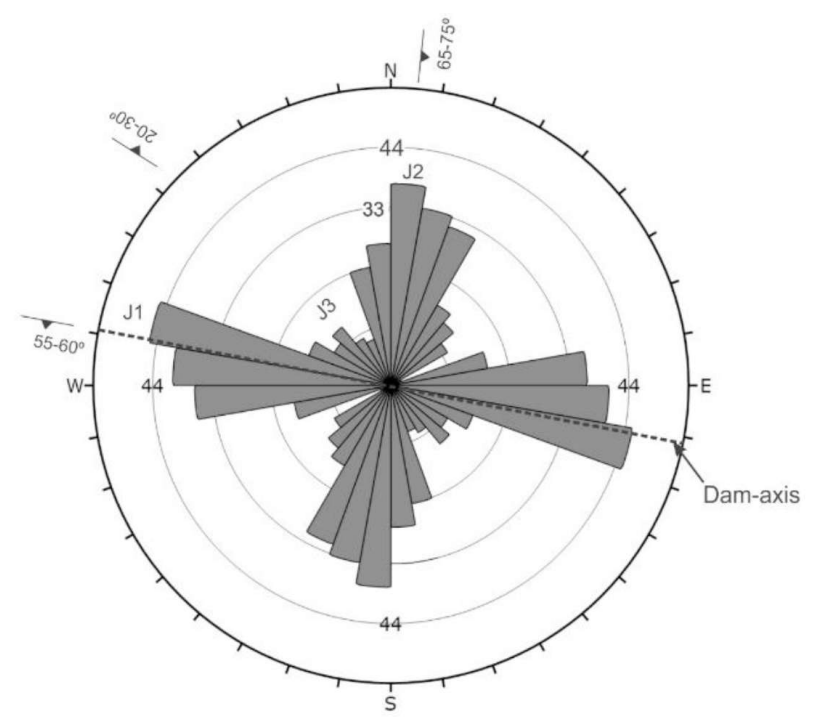

Fig. 6: Rosette plot showing strike of major joint sets along with the orientation of dam-axis

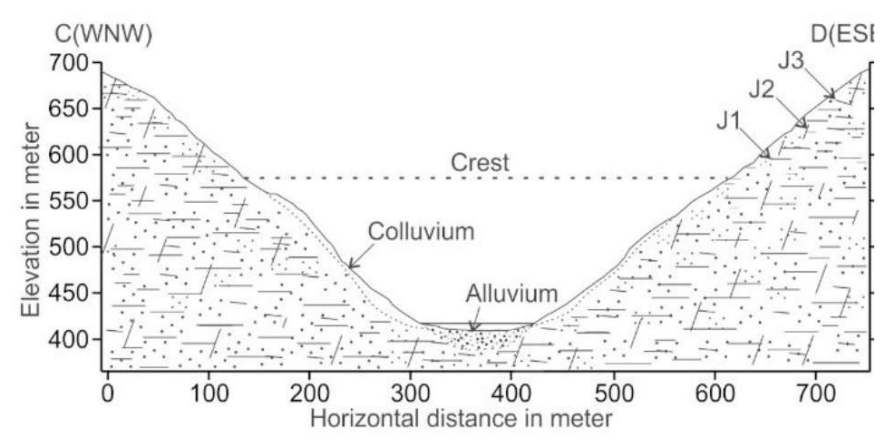

Fig. 5: Cross-section along dam-axis 2

\section{DISCUSSION}

Cross-sections along the dam axis show that the ratio of crest length to height of the dam from valley bottom is such that a narrow valley is formed. River width at 'dam-axis 2' is wider than at 'dam-axis 1'. Also, its length along the crest is 15 to $20 \mathrm{~m}$ longer. Hence, construction of dam at dam site 2 requires more construction materials. Dip direction of rocks at dam site is favorable to prevent the water stored in the dam lake from escaping under the dam. In other words, the dam site is ideal in terms of water retention as rock type is supposed to have very low permeability as well as the direction of the discontinuities is nearly parallel to the axis of the dam and inclined upstream. As the lithology at the dam site area is quite complex with an assemblage of rock types with different susceptibilities to weathering, the grade of weathering is highly varying. This rises question about future weathering that would cause failure of slopes and adjacent structures during their engineering lifetime. Rock mass rating and Dam mass rating approaches of rock mass characterization show that 'dam-axis 1 ' has better rock masses at abutments and in the foundation, with no primary concern related to sliding and failure.

The narrowness of the gorge and the steepness of the stream gradient, gives the impression that the gorge may have been formed along a fault plane, but the detailed study of the stratigraphy and beds that can be correlated on the two abutments do not support the hypothesis. Evidences from mapping and discontinuity studies indicate the gorge is most probably developed along a major joint pattern. The dam founded on rocks dipping upstream represent ideal foundation conditions, they are the most capable of bearing the weight of dam (vertical component- V) and different sort of pressure from reservoir (horizontal component- H). This is because the resultant of these two forces (R) acts nearly at right angles to the bedding planes of rocks (as shown in Fig. 8). Furthermore, if base of dam is adhered properly with foundation rocks, the upstream dip of the strata does not allow the water in the reservoir to percolate below the dam and hence minimizes the risk of elevated uplift pressure and seepage.

Fractures are identified into two broad types: (a) systematic, which are planar, and more regular in distribution; 


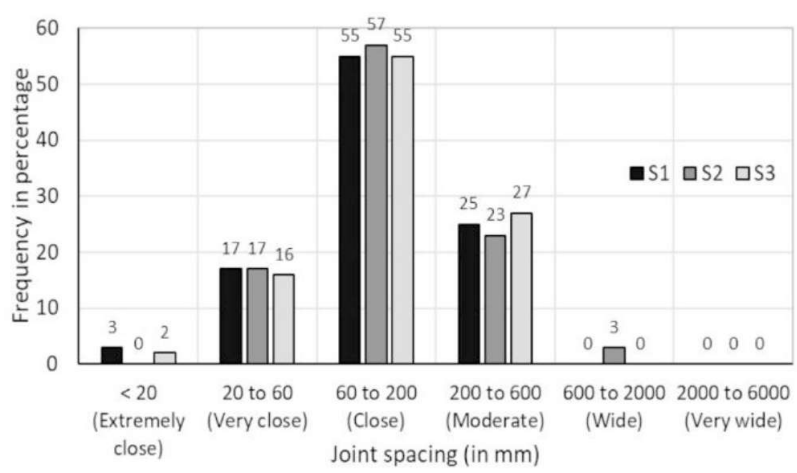

a.

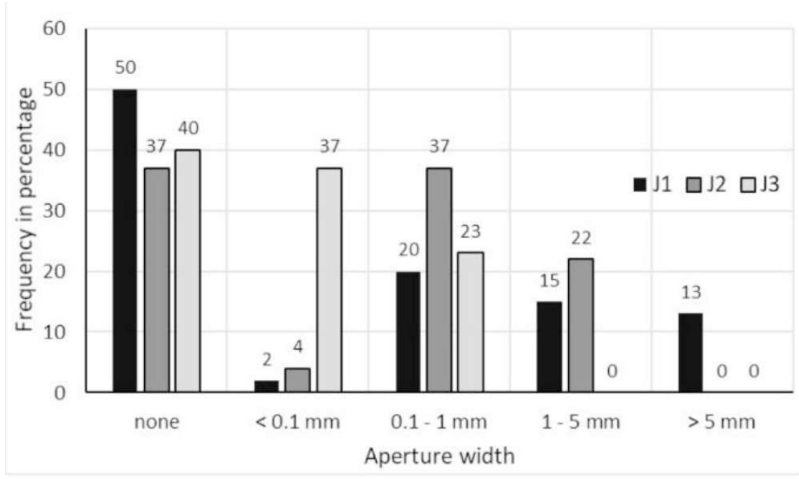

C.

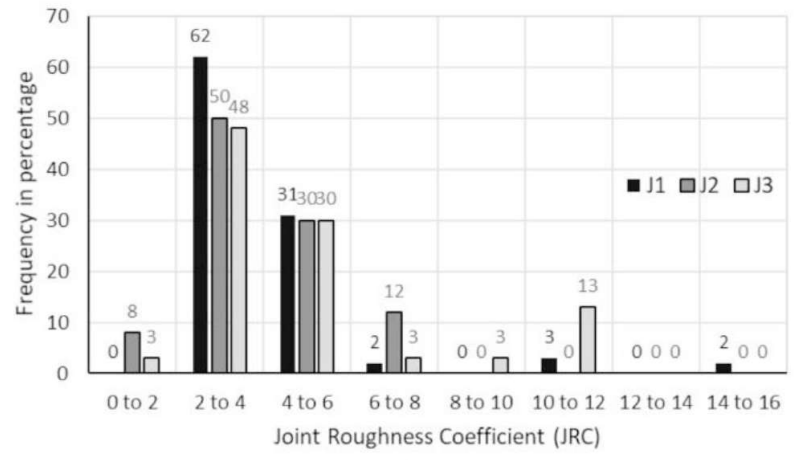

b.

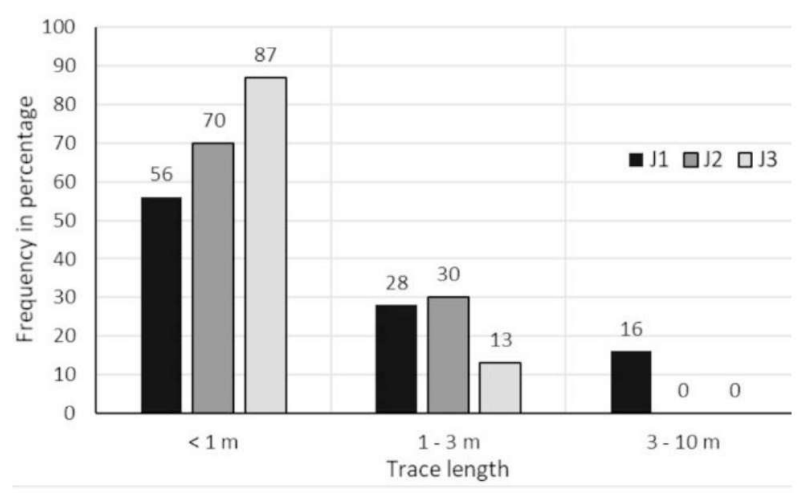

d.

Fig. 7: Graphical presentation of important discontinuity parameters measured at exposures, at and near the dam-axis; a. Joint spacing, b. Joint Roughness Coefficient, c. Aperture width, and d. Trace length

and (b) non-systematic, which are irregular and curved (some of which are stepped). The non-systematic fractures meet but not found cross other fractures and joints, are curved in and terminate at bedding surface or within the same bed where they initiate. Dilational fractures, which are of tensile origin, commonly, developed perpendicular to the foliation plane, and are open fractures with no evidence of shear movement, are of great significance since the persistence of aperture is unknown in most of them.

\section{CONCLUSIONS}

Although exploratory adits or pits were not made, fairly continuous exposures of rocks provided good assessment of discontinuities. The engineering geological map of the dam site shows several faults; however, their displacement (few centimeters) is negligible. Some of the shears are important and would require special consideration if exposed near the foundation during preparation works; however, no surface evidence of these faults being active was seen. It may be very difficult to clean the joints and fracture completely from the clay material (especially those in aperture of foliation plane) before consolidation grouting, that is why the proper effectiveness of the grouting for improvement of permeability and consolidation has been doubted.
Although both proposed dam-axes are near to each other, 'dam-axis 1' is regarded as a better option. Also, as buttress dam requires much less construction materials, it is found more suitable than gravity dam. In the area lying within seismically active region, earth-fill embankment dam would also be better option in such site. Availability of fine soils in a form of residual soil deposits and terraces in near proximity (Ratmate) is an advantage.

\section{ACKNOWLEDGEMENTS}

We would like to express our sincere gratitude to the Central Department of Geology for providing support for the work. We offer special thanks to I. Lamsal, M. K. Rai and N. Parajuli for their co-operation and essential support throughout the study.

\section{REFERENCES}

Bieniawski, Z.T., 1989, Engineering rock mass classification. John Wiley \& Sons, New York, 252 p.

ISRM, 1978, Suggested methods for the quantitative description of discontinuities in rock masses. Int. J. Rock Mech. Min.

Sci. and Geomech. Abstr., v. 15(6), pp. 319-368. Palmström, A., 2005, Measurements of and Correlations between 


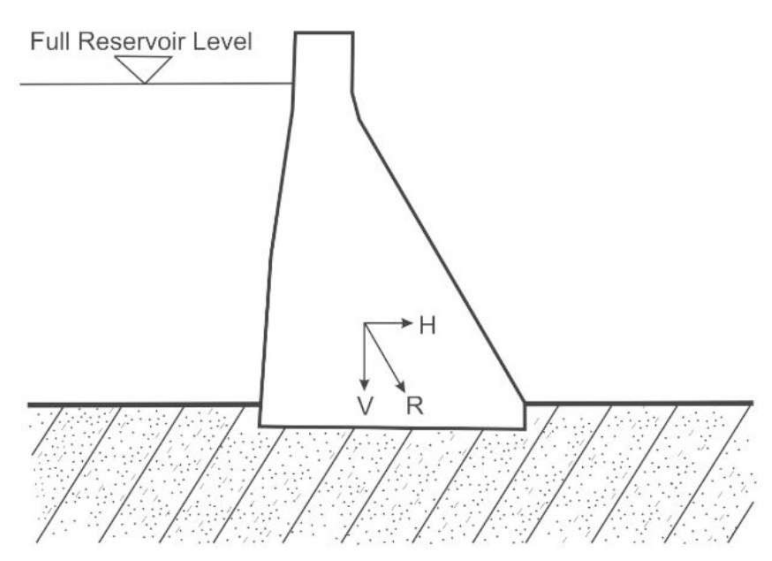

Fig. 8: Schematic diagram of dam showing the direction of resultant force acting upon the rock strata dipping upstream
Block Size and Rock Quality Designation (RQD). Tunnels and Underground Space Technology, pp. 362-377. https://doi.org/10.1016/j.tust.2005.01.005

Romana, M., 2004, DMR (an adaptation of RMR), a new geomechanics classification for use in dam foundations. Proceedings 9th Congresso Luso de Geotecnia. Aveiro, Lisboa, Portugal.

Shafiei, A., and Maurice, B. D., 2007, Rock Mass Characterization at the Proposed Khorram-Roud Dam Site in Western Iran. https://doi.org/10.1201/NOE0415444019c133 https://www.researchgate.net/publication/266203449 [13 April 2018].

Shrestha, S.B. and Shrestha, J.N., 1984, Geological map of Eastern Nepal. Department of Mines and Geology, Kathmandu. 